\title{
East German media in transition after reunification
}

\author{
Maria von Harpe \\ Guest Lecturer \\ Department of English Language and Literature \\ with German, French and Translation studies ${ }^{1}$ \\ Potchefstroom University for CHE \\ POTCHEFSTROOM
}

\begin{abstract}
East German media in transition after reunification

This article analyses the issue of how the "post-socialist" civil society of the former GDR can be reconstructed to reduce dependence of the media on the state and on future private ownership, thereby maximising freedom of communication.

The media had a powerful impact on the transitional phase following reunification. Before 1989 West German television and radio stations were "windows to the West". After reunification East Germans preferred to have their own newspapers, to watch their own television programmes or to listen to their own radio programmes. There has been some criticism about the quality of the media, but the majority of the contemporary audience is satisfied now. To meet the expectations of their audience the journalists themselves have learned to devote special attention to East German problems.
\end{abstract}

One problem of concern is media concentration. Privatisation entails the danger that monopolising trends in mass media, especially in newspaper publishing, will continue in the new East German Lander.

Deregulation and quality programming offer an opportunity for a major breakthrough and new forms of media organisation and management. The period of acclimatisation following the reunification has, however, been too short for the mass media. Nevertheless, owing to specific characteristics of reunification, the transition East Germans have had to make has been largely successful.

1 Since 1995 Dr. Maria von Harpe has annually lectured in the Department of English Language and Literature with German, French and Translation Studies at the Potchefstroom University for CHE. For the greater part of each year she lectures at the University of Bonn. 


\section{Introduction}

This paper analyses the changes in media systems as well as the influence of the media on the transition process, i.e. responses to new economic, political, and social circumstances. The main question is whether and how a "post-socialist" civil society, like the former GDR, can be reconstructed to reduce the dependence of the media on the state, while also minimising dependence on future private ownership to maximise freedom of communication.

\section{Special role of mass media in the peaceful revolution of $\mathbf{1 9 8 9}$}

(The) primary job (of the Ministry of Truth) was not to reconstruct the past but to supply the citizens of Oceanic with newspapers, films, textbooks, telescreen programmes, plays, novels - with every conceivable kind of information, instruction or entertainment, from a stature to a slogan, from a lyric poem to a biological treatise, from a child's spelling book to a Newspeak dictatory (George Orwell, 1992:45).

Like George Orwell's Ministry of Truth the centralised government of the German Democratic Republic (GDR) controlled the mass media before reunification. This is why the news about the Berlin Wall surprised everyone. In fact, the news of the Berlin wall coming down on 9 November 1989 was based on a misunderstanding between Politburo member Günter Schabowski and the media, a spontaneous action not supported by the former Soviet Union. In a press conference, Schabowski explained that everyone could travel wherever he/she pleased and that the borders to the Eastern States were in the process of being reopened. When a journalist asked whether this was true for all East German borders, Schabowski answered in the affirmative. West German television and radio broadcast this news at once with the result that thousands of East Germans began crossing the border to West Germany (Nölte, 1991:36).

The collapse of the Wall on 9 November 1989 was a decisive contribution to the realisation of East Germans' expectations of freedom. It was generally agreed that this was the end of communism and perhaps the end of socialism as well. It is now clear that there was no possibility of turning back; almost overnight parliamentary democracy was achieved. Some historians state that the peaceful revolution of 1989 in Eastern Central Europe, especially in East Germany, will be epoch-making in the same way as were the events of the year 1689 in England (Bill of Rights), or the French Revolution in 1789 (the end of the Ancienne Régime).

Many developments led to this unexpected and peaceful transition including the following: 
- The global revolution process in East Central Europe caused profound social transformation at every level, from the intellectual to the economic level (Fukayama, 1992). Although observers of the Communist nations of Eastern Europe had long viewed East Germany as fundamentally different from its socialist neighbours, its Communist regime, nevertheless, collapsed at the same time.

- The USSR was also changing. Gorbachev came to East Berlin to conduct an open dialogue with all groups in society, but said that the Soviet Union would not intrude on East German's affairs. Honecker said that no change was needed and that Bonn "had mounted an unbridled campaign against his country" (International Herald Tribune, 1989-10-7/8; see Anon., 1989). The East German government was not prepared to follow Gorbachev's policy of Glasnost.

- Eighty percent (Hesse, 1988) of all East Germans had watched Western television and listened to radio programmes of the West for years ${ }^{2}$. East Germans preferred to obtain their information from independent media; they paid little or no attention to their own media because of censorship.

- Western television and radio made East Germans aware of large economic disparities between the FRG and the GDR.

- The development of new technologies was fast and amazing. In the long run a totalitarian state like the GDR situated next to West Germany and in the centre of Europe undoubtedly would have lost power, had it allowed East Germans to have access to the new technologies. ${ }^{3}$

- The mass exodus from the GDR astonished East and West Germans and their allies for months.

On 18 March 1990 East German citizens voted in GDR elections for German unity with the result that the GDR disappeared. All responsible politicians, whether East or West German, called attention to integrate the German unification process into international context. Both German governments were

2 It is amazing that it was forbidden to take newspapers, periodicals, books or other written material across the border. On the other hand, the East German government gave up turning the antennas on the roof of houses toward the East in order to prevent East German citizens from watching Western TV.

3 Before the revolution the number of copying machines e.g. had been registered, the only way to copy a text was to use a typewriter and carbon copy paper. 
faced with the task of establishing consensus with their neighbours and with the Four Powers of 1945, Britain, France, the Soviet Union and the United States.

\section{Development of the media structure}

\subsection{Media as an instrument of government power}

Harold D. Lasswell (1963:111) once said: "(Political) propaganda consists of political symbols for the control of public opinion."

In a similar way, Mephistopheles proposed in Goethe's Faust (1981:75/76)4:

In words let your attention center.

Then through the safest gate you'll enter

The temple halls of Certainty ...

With words 'tis excellent disputing;

Systems to words 'tis easy suiting ...

(Translator: Bayard Taylor.)

This was the advice taken by the GDR in building up its centralised structure. Until 9 November 1989, nearly all East German media was under SED-Politburo control (except church-related newspapers). The department of Agitprop (see diagram) was responsible for controlling anything that was to be published. This control also included the language that was used in mass media - language that was clearly manipulated for propaganda purposes, a language nourished by the roots of Marxist-Leninist ideology: "Language is an instrument in the struggle and development of society." This basic idea of Marxist-Leninist ideology determined the language used in newspapers for years. Words like the following were introduced: Klassenkampf. Ausbeutung, Revolution, imperialistischer Hegemonialanspruch, Held der Arbeit. Antifaschistischer Schutzwall ("antifascist protective wall") was an euphemism used for the "Berlin Wall".

After the reunification journalists were called on to avoid these words and to use new ones for example, "social market system". The language of the East German propaganda was called kommunistische Begriffsverdrehung, Sowjetdeutsch, Funktionärsjargon by the West German media. Before 1989, every journalist was supposed to speak basic Russian because a number of new Russian words had been introduced into the East German mass media - words such as Pjatiletka

4 Im ganzen: haltet Euch an Worte! dann geht lhr durch die sichre Pforte Zum Tempel der Gewißheit ein .. Mit Worten laßt sich trefflich streiten. Mit Worten ein System bereiten ... 
= five-year plan, Kolchosnik $=$ labourer of a collective farm, Milizionär = policemen). In the same way names of cities were changed, for example Karlovy Vary (Karlsbad"), Kaliningrad (Königsberg), Gdansk (Danzig).

In the old nomenclature system, it was clear that those who held leading positions in the media were dependent on the ruling power. Consequently, no real censorship was necessary. Politburo member Günter Schabowski once said: "The editors themselves were a political institution. No one was better qualified to control what should be published than they" (Sieren, 1990:43).

This was true because the education of journalists was under SED-control. Only the politically reliable had the opportunity to study journalism: More than 80 percent were SED-members. East German journalists were said to have reported half-truths and perverted the facts although there was no (official) censorship. Thus, the credibility of the mass media in the GDR was very low. Nobody believed in the information the media published. People paid little or no attention to propaganda because of unofficial censorship. About 80 percent of East Germans watched West German television, which had a very high credibility rate. In the autumn of 1989, while East German television (Actual Camera) still demonstrated the controlling power of the socialist state, West German television (ARD and ZDF) was already reporting on the mass exodus and on how thousands of East Germans were leaving via Prague for the West (Ludes, 1991:31). As those who remained in the GDR watched interviews with deportees, political opposition grew in the GDR. Many East Germans arriving in the West were interviewed by ARD or ZDF. This strengthened the political opposition in the GDR. The East German media were still under the control of Joachim Herrmann, the head of the Politburo department Agitation and propaganda, and bound by directive No. 4: Make no comment on topics like mass exodus (see Neue Zeit, 1990-01-19; Anon., 1990). The media also were not to focus on, among others, environmental or economic problems.

\subsection{The Media Control Council and the Public Advisory Board}

Three phases divided the transition from the fall of 1989 to the fall of 1990 :

- Direct publishing control of the SED Politburo ended.

- Journalists hoped that new structures, new managements and regulations would promote media independence.

- Fornerly state dominated media became market oriented media. This led to the bankruptcies of many newspapers in the New Federal States. 


\section{Centralised mass media in the GDR}

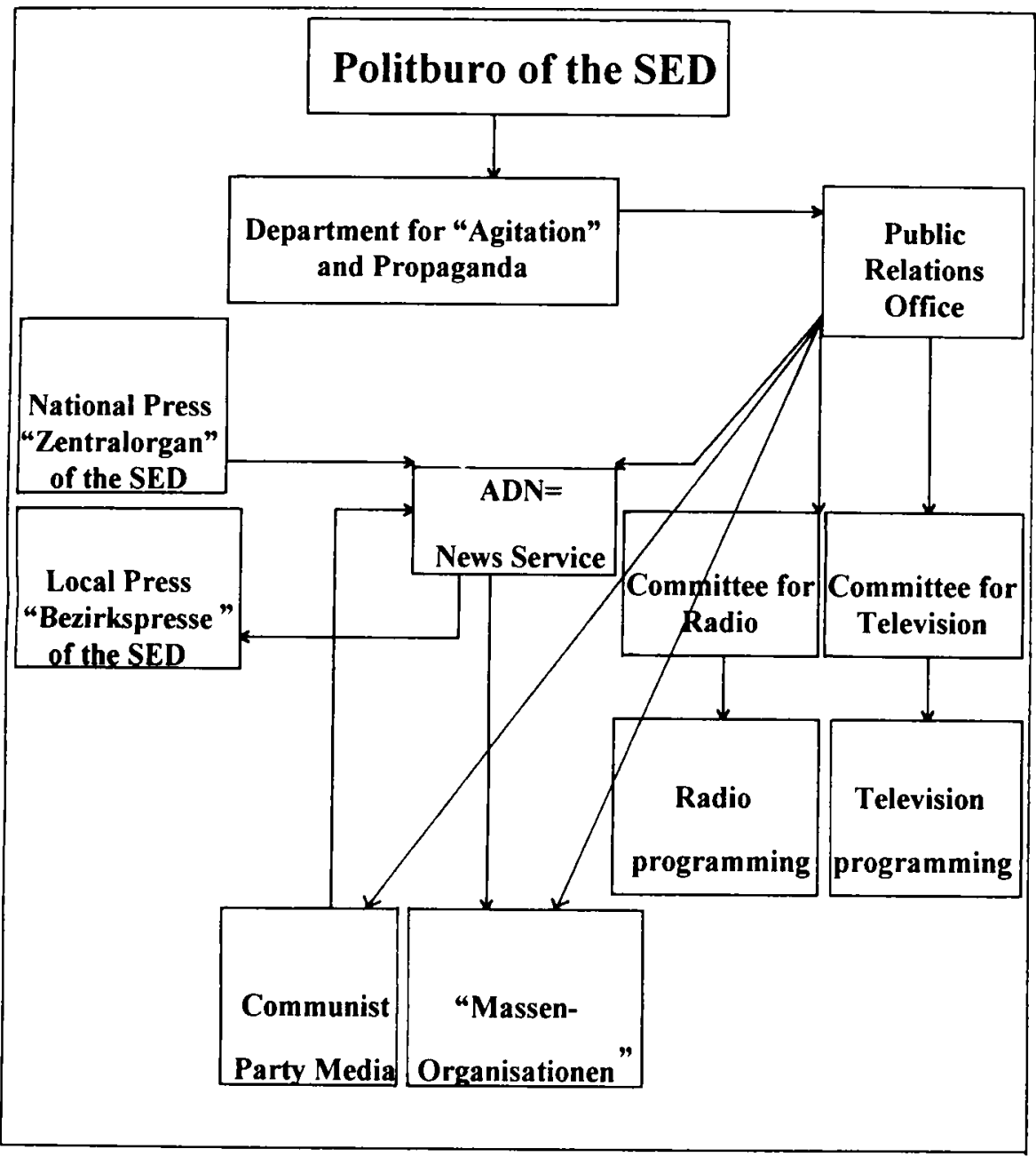

Source: Bundesministerium für innerdeutsche Beziehungen; see Anon., 1981:76 
After strong regulation and control, most journalists saw media commercialisation as the key to achieving autonomy from the state. There were, however, two obstacles, one economic and one ideological. The media needed fresh capital for practicable, efficient, and not simply nominal privatisation. East German journalists were, however, also exposed to the danger of excessive power resulting from an injection of pure capital in this sensitive sector.

When mass demonstrations took place in Leipzig, as a result of which Honecker and Joachim Herrmann both resigned, many journalists no longer needed the government's censors. All leading SED members were replaced by members less involved in politics. Above all it was a time when journalists started writing according to their conscience. But this did not last very long. By 1990, more and more East Germans were asking for unification and the East German system of districts (Bezirke) was replaced by five federal states.

In December 1989, the People's Chamber voted to expunge the SED's leading role from the East German Constitution; a week later East German civil movement (Bürgerbewegung) representatives at Round Table talks were put in power. The Round Table established a media law working group. Fifty Round Table participants representing parties, churches, lobbies, and the media became members of a special commission in December 1989. This commission was asked to create guidelines for a transitional solution. One important point of discussion was that after forty years of censorship East Germans were no longer prepared to delegate responsibility to political parties.

In addition, a resolution was drafted asking for the "right of reply" (Gegendarstellung) to be guaranteed in the same medium in cases where the correctness of "facts" could be disputed. East Germans had never known a "right of reply". The initial intention was to protect the individual from state or political party interests. Then it was to protect them from sensationalist press media.

On 5 February 1990, these guidelines were ratified by the People's Chamber. Article 12 provided for the founding of a Media Control Council. The task of this Council was to monitor respect of the guidelines. On 13 February 1990, the Media Control Council was established, lasting even longer than the Round Table itself: that is, until 19 September 1990 - two weeks before unification. Twentyfour representations of socially relevant groups became members of this body. The Media Control Council, which had no real power to punish offenses against the guidelines, was compared to a wolf without teeth. Nevertheless, its existence was important for the media system. From February until 3 October 1990 the electronic media and the newspaper agencies were placed under the supervision of the Media Control Council. 
National elections were held on 18 March 1990. The victor was the Christian Democratic Union (East CDU), a traditional party from the Communist era, but now allied with the West German CDU led by Chancellor Kohl.

The first post-Communist Prime Minister, Lothar de Mazière (CDU), surprised the media reformers by establishing a Ministry of Media Policy (Boyle, 1994:197). This action was surprising because the Media Control Council was supposed to remain in power until the adoption of the new constitution. Media reformers had expected that the Media Control Council and the commission would draft a new Media Law so that it could continue making proposals for a new media structure.

At the same time the Ministry of Justice established a Commission to draft the new Media Law.

\subsection{Article 36 of the Unification Treaty}

According to Article 36 of the Unification Treaty (see Anon., 1991:182-183) the five newly created federal states (formerly the GDR) were obligated to develop press laws within their state constitution, and establish public broadcasting corporations by December 1991. After that date all former broadcasting operations were to be shut down. Article 36 also called for the appointment of a commissioner and an elected eighteen-member broadcasting advisory board, with three members from each state, to oversee the transition to a federal broadcasting system. When the Unification Treaty was signed on 31 August 1990, Prime Minister Lothar de Maizière was supposed to make a nomination but he never did. Manfred Becker (SPD), the Secretary of the East German Media Ministry, and West German journalists assumed that Chancellor Kohl's strategy was to buy time and to try to orchestrate East CDU media policy (Boyle, 1994:199ff). Two months later - in November 1990, after the reunification and election in the federal states (the CDU won the majority of the new federal states) - each state put forward a nomination for commissioners. The CDU candidate, Rudolf Mühlfenzl, the former chief of the Bavarian Public Broadcasting corporation, was elected.

Rudolf Münzfenzl held this position until the GDR broadcasting organisations were officially dissolved on 31 December 1991. Broadcasting commissioner Rudolf Münzfenzl and his eighteen-member Broadcasting Advisory Board had to assist the five new federal states in developing their public broadcasting organisational structure and in distributing physical resources such as the studios of the centralised GDR among new federal states. 


\section{Structural development from party dependent media to more privately based media}

\subsection{The new East German journalists}

An East German journalist once said: Before 1989 the guidelines for publishing came from the Politburo in East Berlin. After the wall had fallen most of the high level positions were taken by the "Wessies" (from West Germany). In the old Nomenklatura system it was clear that those who had held leading positions in the media were dependent on the ruling power.

Because of SED influence on the education of journalists and on the choice of those entering the position (nearly $85 \%$ were party members - Boyle, 1994:205), West Germans looking for candidates for higher level positions had a great mistrust of East Germans. The common excuse of the West Germans was that the candidates had no experience of a free media system. Of course, this was no reason for West Gennans to occupy all these positions. Sometimes even the new technical director would be a Wessi. When former East German journalists were allowed to stay in office, they were very often downgraded. Moreover, the East Germans complained that they had to focus on topics of Western interest. "The Wessies decide and determine priorities and often do not meet the real needs of the East German people" (Streul, 1993:42). During the first few years after reunification, the MDR (Mitteldeutscher Rundfunk, a regional television network) preferred to offer infotainment (mix of information and entertainment) and crime series (Grubitsch, 1992) instead of providing basic information.

Besides this, the new management decided to focus on topics like environmental protection, topics that were completely new to the East German people and therefore not of primary importance. Media consumers in the new federal states expected more pragmatic information on the transition process or simple information on topics like the operation of the tax system and the social market system or ways to avoid unemployment.

Many East German journalists long hoped for professional independence and freedom of the press. Within a very short time, articles appeared in East German newspapers that demonstrated pluralistic political views. The journalists considered media commercialisation an important instrument to achieve autonomy. In the past, the position of journalists had been secure, but state dependent.

\subsection{The new broadcasting: Television networks and radio stations in transition}

All mass media broadcasting was under the control of the Agitprop department of the SED and supervised by two committees, one dealing with radio, the other 
with television (see diagram - p. 188). By the end of 1989, two East German television channels emerged. By December 1991, one of these channels had started broadcasting: ARD (the West German federalised public broadcast network, established on decentralised lines) as well as other networks, exclusively of interest for East Germans, continued to operate.

As mentioned above, by 31 December 1991, the new private and public broadcasting corporation order was in place as provided by Article 36 of the Unification Treaty. The federal states had to include comprehensive press and broadcasting provisions in their new constitutions. Two new East German broadcasting corporations were founded. Each offered three television channels and several local radio stations which were supervised by citizen advisory councils. The councils' responsibility included establishing programme objectives, budget approval, and senior personnel decisions. One of these two organisations was the Middle German Broadcasting Corporation (MDR) founded by the three biggest new federal states, Saxony, Thuringia, and Saxony-Anhalt, according to the West German model, the North German Broadcasting. Corporation (NDR). Brandenburg founded its own broadcasting corporation, the East German Broadcasting Corporation of Brandenburg (ORB). MecklenburgWestern Pomerania joined the North German Corporation (NDR) and Berlin the Sender Freies Berlin which was a result of the special status of Berlin as early as 1990. The federal states Berlin and Brandenburg signed a treaty under which they agreed to cooperate more closely to use resources in a more effective way.

In the beginning, East German television regional networks did not meet East German expectations. They reported on "East Germans" in a rather passive or pessimistic way. The networks did not meet the specific needs of East Germans. There were discussions about guilt and morality in the Communist era, but never about the advantages of the GDR, for example, its kindergarten policy, which had been much more advanced in East Germany prior to reunification.

By the end of 1990, most radio stations were located in East Berlin because of their dependence on GDR broadcasting facilities. There had been only a few local stations of minor importance. After unification East Germans adopted the radio broadcasting system of West Germans, the so-called dual system. Radio frequencies were allocated to private broadcasters in each federal state.

In Germany, about 200 radio stations are presently operating, either regionally or locally, and the majority of these are privately run. Nearly all radio stations sell commercial time, although the public radio stations are generally restricted to broadcasting not more than 90 minutes of advertising within any one 24-hour day.

The transition from Communist totalitarianism to democracy was clear in 
television broadcasting. The end of Communist control was followed by a combination of an overtly political attitude to television and a surrender to large commercial interests.

The present broadcasting landscape in Germany is marked by a national public system (independent corporations under public law) and a number of private and semi-private competitors. There are four main national television channels: ARD, ZDF (both public; ARD is decentralised, and comprises state and regional programs; ZDF transmits a nationwide program) as do RTL and SAT 1 (privately owned commercial stations). Germans who have access to satellite or broadband cable are able to receive about 25 German-language television channels. The improvement of communication technologies is still in progress.

As in most West European countries, privatisation and deregulation in broadcasting have led to a concentration of media in private ownership. Consequently, media choice and the professional autonomy of journalists are urgently needed in order to maintain a certain level of pluralism.

\subsection{Newspapers}

During the reunification process, it was clear that special rules were applied to the East German newspaper market. In the former GDR, 38 daily newspapers had been published since 1952. Then the GDR was divided into 15 Districts (Bezirke). The SED offered each Bezirk one SED-controlled newspaper with a section devoted to local concerns. There were also 14 other newspapers offered by the Communist parties (Blockparteien). Numbers of copies were limited and therefore unimportant.

The seven largest newspapers, called Zentralorgane (centralised national newspapers that were offered nationwide), were published in East Berlin and reached a third of all GDR readers. People preferred these newspapers to regional ones, not because of the quality of information (the information was mostly propaganda and newspapers had only about eight pages), but because the Zentralorgane were subsidised and consequently inexpensive.

After reunification, "party dependent press" developed into a "privately based press" (Streul, 1993:43). Many private publishing houses founded newspapers. In 1990 seventy newspapers were published in East Germany. In Leipzig or in Thuringia seven local newspapers were on the market at the same time. It is obvious that most of them could not survive because of the high competition, but there were also other reasons. The old management of the newspapers did not have enough experience in financing a free press and soliciting advertising. Moreover, East Germany was not a big advertising market. Many West Germans 
invested in East German newspapers or set up new newspapers in the hope of making money. However, nearly 50 percent failed.

This was not true of the fifteen SED newspapers. They were sold by the Treuhand, a temporary organisation founded by the German government to privatise most of the former GDR's property. Because West German publishers saw a very good chance to make use of established distribution markets, the publishers bought the old SED newspapers and in most cases succeeded. After several years of competition, these newspapers were able to increase their share of the overall newspaper market to 91 percent in the federal states (Presse und Informationsamt der Bundesregierung; see Anon., 1994:88). Such a large concentration is understandable but under the law against media concentration (Gesetz gegen Wettbewerbsbeschränkungen, 1990:235) the selling of the SED newspapers to big publishers was considered appropriate. The German government even claimed that if it had delayed privatisation, the newspaper market structures would have been even worse (Presse und Informationsamt der Bundesregierung; see Anon., 1994:245). On the other hand, such a concentration could have been avoided by adopting, for example, the Swedish newspaper market-model. In Sweden, the market mechanism is regarded as inadequate; the state intervenes to support newspapers.

Big publishing firms, for example, Gruner, Jahr and Maxwell, which had bought the former SED Berliner Verlag, adapted several publications to meet the expectations of readers by focusing on East German problems.

It was clear from the beginning that the East German reader would ask for a different type of newspaper and magazine than the West German. In 1990 four million copies of the 223 different West German publications were sold, but the East Germans preferred the less expensive ones (Meyn, 1994:78). Magazines like Spiegel, Stern or Die Zeit thus failed to sell in large numbers.

\section{Summary}

G.A. Miller (1963:269) stated that the influence of media succeeds if all channels are under complete control of propagandists and counterarguments are never presented in any media. This was true for Eastern Central Europe under the former socialist regimes. But changes in the media structure of the GDR differed completely from those in other Eastern Central European countries. Owing to the process of unification, conditions for economic development were much better than in other Eastern European countries.

The democratisation process was a big challenge. The media had an important impact on the transition process. Changes in the media system represented an important issue of a predominantly political nature. 
There was a big change in the broadcasting sector. Before 1989, East Germans used West German television and radio stations as a "window to the West". As mentioned previously in this article, 80 percent of East Germans watched West German television. After reunification, East Germans preferred to have their own newspapers, to watch their own television programmes and to listen to their own radio programmes. Although at the beginning there was some criticism about the quality of the programmes, the majority of East Germans are satisfied now. The journalists themselves have learned to focus on special East German problems to meet the expectations of their audience. Even today, the daily West Berlin newspaper Berliner Morgenpost devotes one page to topics from the East to serve the interests of East German readers.

Yet the problem of media concentration remains. Privatisation also involves the danger that monopolising trends in mass media would continue in the new federal states. The cartel authority is carefully watching the market. In most cases, a simple warning from the cartel supervising authority has prevented publishers from carrying out their plans; even when the publishers have expressed only an intention that could lead to an offense.

Deregulation, quality programming, and new forms of media organisation and management offered a chance for a major breakthrough, but the transition period was too short. During the busy years, the media followed party lines and were bound by the division of quotas. As commercial aspects grow in importance, limitations on profit-making principles must exceed the present regulations.

A good balance of private ownership and public regulation could improve the quality of information and entertainment. The option exists of shaping market transactions by political and legal regulations to avoid monopolies.

After reunification, journalists hoped to create a new kind of media that would be based on public funding and not controlled by the state, while the state would enforce certain political and legal regulations to prevent monopolisation and the domination of commercial interest. The principal question is: How can the power of private ownership and political institutions be restricted to protect the independence of the media and to serve consumer interests in the best possible way? Regarding newspapers, Sweden is a good example. As mentioned above, disadvantaged newspapers negatively affected by a deficient market mechanism are subsidised.

There has already been and there will continue to be a more international, and particularly European influence on the mass media. Media owners are no longer national companies but international publishers. In the same way that the German publisher Springer acquired a significant share of party media in Hungary, the 
British publisher Maxwell, together with Gruner and Jahr, bought shares of the former SED publishing firm. This shows the dependence of Eastern countries on Western capital and know-how.

European guidelines must be taken into account in drafting new media laws, for example, the new interstate state treaty on broadcasting, valid from January 1992, on harmonised European regulations for television broadcasting.

The main question posed by this article was whether and how a "post-socialist" civil society like the former GDR could be reconstructed to reduce dependence of the media on the state and future private ownership to maximise freedom of communication. The special situation of reunification has led to an overall successful transition of mass media. There was a change from direct publishing control to consumer-oriented media with private ownership within certain public guidelines.

In the last decade television programmes has broadcast in a very emotional way the peaceful and growing revolution in East Germany and the mass exodus to the West.

In this decade television will have to face its most challenging task: helping the Germans to overcome the idea of the "Berlin Wall", the symbol of separation.

\section{Bibliography}

Anon. 1981. Zahlenspiegel, Bundesrepublik Deutschland/ Deutsche Demokratische Republik - Ein Vergleich. Gesamtdeutsches Institut, Bonn : Bundesministerium für innerdeutsche Beziehungen.

Anon. 1989. Open Dialogue, Gorbachev Says in East Berlin. But Honecker Vows to Resist "Weakening of Communism". International Herald Tribune, October 7-8.

Anon. 1990. Wir beschäftigen uns nicht mit Ausreisepolitik. 4. Direktive des SED Agitationschefs aus: Was der Leser wissen darf, das entscheiden wir! Neue Zeit, Jan. 19.

Anon. 1991. Article 36 des Einigungsvertrages. In: Claus, W. Medien-Wende-Wende Medien, Dokumentation des Wandels im DDR-Journalismus. Oktober 1989-Oktober 1990. Berlin : Vistas Verlag GmbH. p. 182/183.

Anon. 1994. Medienbericht ' 94 . Bonn : Presse und Informationsamt der Bundesregierung. Boyle, Maryellen. 1994. Building a Communicative Democracy: The Birth and Death of Citizen Politics in East Germany. Media, Culture \& Society: 183-215, April.

Fukayama, F. 1992. The End of History and Last Man. Hammondsworth : Penguin.

Gesetz gegen Wettbewerbsbeschränkungen. 1990. BGBL. I, S2486, i.d.Fassung der Neubekanntmachung vom 20. Februar 1990 (BGBL).I. p. 235.

Goethe, Johann Wolfgang. 1981. Faust. Frankfurt : Insel Verlag.

Grubitzsch, Jürgen. 1992. Nur der Kommissar steht hoch in der Gunst und den Einschaltquoten. Süddeutsche Zeitung: Sept. 14.

Hesse, Kurt. 1988. Westmedien in der DDR. Nutzung. Image, und Auswirkungen bundesrepublikanischen Hörfunks und Fernsehens. Köln : Wissenschaft und Politik. 
Lasswell, Harold \& Kaplan, A. 1963. Power and Society. New Haven. p. 111.

Ludes, Peter. 1991. Von mir hätten Sie nur die halbe Wahrheit bekommen. Aus Politik und Zeitgeschichte, 17(9):22-31.

Meyn, Hermann. 1994. Massenmedien in der Bundesrepublik. Berlin : Colloquium Verlag.

Miller, G.A. 1963. Language and Communication. New York : McGraw Hill.

Nölte, Joachim. 1991. Chronik mediapolitischer Ereignisse in der DDR. In: Claus, W. (ed.). Medien-Wende-Wende Medien, Dokumentation des Wandels im DDR-Journalismus;

Oktober 1989 - Oktober 1990. Berlin : Vistas Verlag GmbH. p. 17-116.

Orwell, George. 1992. 1984. New York: Alfred A. Knopf.

Sieren, F. \& Koehne, L. 1990. Das Politbüro. Hamburg.

Streul, Irene Charlotte. 1993. Die Umgestaltung des Mediensystems in Ostdeutschland. Aus Politik und Zeitgeschichte, 40(93):36-46. 
